\section{E-LOGOS}

ELECTRONIC JOURNAL FOR PHILOSOPHY ISSN 1211-0442

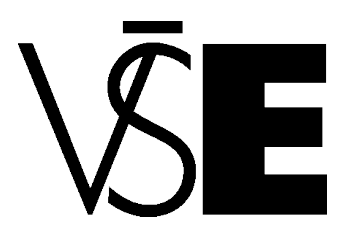

University of Economics

Prague

\title{
To the Interpretation of Spontaneous Order
}

\author{
Petr Špecián
}




\begin{abstract}
The article analyzes basic reasons for renewed interest in Alfred Schutz's works by the Austrian economists in the context of postmodern criticism of aprioristic methods of praxeology and foundational paradigm as such. It also deals with the possible applications of Schutzian method of telescopic ideal type on the problem of spontaneous order and shows this method as a possible alternative to Hayek's evolutionary approach. Phenomenological method that creates a baseline for Schutz is only useful to an extent to which the structures of spontaneous order can be grounded in individual consciousness. In cannot, therefore, be used to answer the question of the origin of spontaneous order but it can provide some answers regarding its reproduction.
\end{abstract}

Keywords: Alfred Schutz, spontaneous order, ideal types, Austrian school 


\section{The Interpretive Turn}

Several important authors affiliating themselves with the Austrian school of economics went through so called interpretive turn (see Lavoie 1994). It has been inspired by the inflow of new ideas related to philosophical postmodernism that has been attractive for the Austrian authors by its disdain for positivist legacy and its "objectivist bias", i.e. especially its emphasis on mathematical formalism and quantitative prediction. These ideas seemed to bear a promise of a return to rather narrative, qualitative economics (Lavoie 2011). According to Klein (1999; 2001), mainstream economics completely misses the role of interpretation and judgment that is necessary to transform an information as something objective and de facto independent on a human being into knowledge - the key step for economics to retain (or gain back) the practical relevance it desires is to take up a dialogue with a "naïve" man in the street, the Everyman.

Postmodern thought entered the field of economics most notably in works of Deirdre (formerly Donald) McCloskey whose article The Rhetoric of Economics (1983) marked the beginning of a methodological dispute that lasts until today. McCloskey stands up against modernism. Especially against prescriptive methodology that stems from the tradition of logical positivism and its effort to demarcate science and nonscience. It is possible to interpret this stance as an opposition against a philosophy that dares to criticize the avocation of economists in deductive reasoning and their frequent loss of touch with real-world problems: ${ }^{1}$

"Philosophy as a set of narrowing rules of evidence should be set aside in scientific argument, as even many philosophers have been saying now for fifty years.

Economics will not change much in sub-stance, of course, when economists recognize that the economic emperor has positively no clothes. He is the same fellow whether philosophically naked or clothed, in reasonably good health aside from his sartorial delusion." (McCloskey 1983, 482)

On the other hand, this stance is also deeply philosophical, developed on a basis of postmodern rejection of an existence of any ultimate foundation for our knowledge (Rorty 2009) and an attempt to supplant the notion of truth as correspondence (adaequatio rei et intellectus) with a notion of local (in both time and space) consensus of the speakers (Lyotard 1992) and forever ongoing process of interpretation of speech and text (Gadamer 2004).

Abandoning of the foundationalist paradigm in the context of Austrian economics would prove fatal especially for Mises' (2010) aprioristic praxeology that, although skeptical to prediction and qualitative in nature, represents exactly the kind of

\footnotetext{
${ }^{1}$ It must be added that in her more recent writings, McCloskey takes quite a different position in this regard (see McCloskey 1996).
} 
thinking that claims to be based on timeless and indubitable truths which is highly suspicious from the postmodern point of view, sometimes even connected with an image of terror (Lyotard 1992). Orthodox proponents of the Misesian model are obviously fully aware of this fact as their rather irritated response to McCloskeyan rhetorical approach to methodology (Hoppe 1989; Rothbard 1989; 1996) as well as great controversy caused by Lavoie's (2011 [1985]) working paper claiming allegiance to this style of thinking testifies more than persuasively (see also Storr 2010a).

\section{Schutz Rediscovered}

In this intellectual context, there occurred a certain renaissance and rediscovery of Alfred Schutz ${ }^{2}$ whose popularity still seems to be rising. ${ }^{3}$ There are probably at least three reasons why the Austrian economists find Schutz interesting:

First, whereas more well-known proponents of the hermeneutical approach as Gadamer or Ricoueur can be close to the Austrians only based on principle "the enemy of my enemy is my friend" (see Storr 2010b), Schutz's works were created in a direct dialogue with Ludwig von Mises and partly also with Friedrich Hayek. Prendergast (1986) shows that Schutz's most important work, The Phenomenology of the Social World (1972), has been written rather for the purpose of a discussion in Mises' private seminar (Miseskreis) than as a contribution to the phenomenological philosophy. Compared with hermeneuticians who can be charged with collectivism or even ties with national socialism (Rothbard 1989), Schutz implements the traditions of Austrian methodological individualism in an authentic fashion and shares the fate of a fugitive from the totalitarian regime (see Grathoff 1989) with many other important figures of the Austrian school including Mises and Hayek.

Second, Schutz shares to some extent the skepticismagainst prescriptive methodology and anti-positivist orientation. His emphasis on interpretation of human action allows us to work on "soft" social-scientific topics and develop the Austrian "humanistic science of society" (Koppl and Whitman 2004) which represents an alternative to overly mathematic mainstream economics (Boettke 1997). The Schutzian framework is also grounded in classical phenomenology and understanding sociology - both approaches are respected within the Austrian school and do not need to be directly connected with "collectivist" hermeneutics. Even Rothbard (2011), otherwise an outspoken critic of all hermeneutics, speaks about Schutz with sympathy.

\footnotetext{
2 For the introductory review of Schutz's work in relation to the Austrian school and methodology of economics see e.g. Prendergast 1986; Vaněk 2004 or Špecián 2011.

${ }^{3}$ Special issue dedicated to Schutz in The Review of Austrian Economics (2001, 14 (2-3)) can be mentioned as well as a new journal Schutzian Research (from 2009 on), or a collective monograph Alfred Schutz and his Intellectual Partners (Nasu et al. 2009).
} 
Third, Schutz always lays emphasis on invariant structures behind the manifold phenomena of the lifeworld and therefore does not advocate postmodern relativism nor radical subjectivism that has been promoted by Ludwig Lachmann (1976) under the inspiration from G. L. S. Shackle. That allows him to avoid Rothbard's $(1989,50)$ biting remark that with everything being relative and subjective, it is far better to "go fishing or get drunk" than to pursue an endless conversation which cannot lead to any conclusion after parting with the notion of an objective truth. Accepting Schutzian approach does not, therefore, represent a radical withdrawal from the positions of praxeology as Špecián (2012) argues - it only opens more space for empirical enquiries on lower levels of abstraction and mitigation of the claims on apodictic character of the basic principles of human action. Schutz thus represents a line of defense against postmodernism as it has been drawn by Pavlík (1998).

The attempts to apply Schutzian insights can be found in in a broad area: e.g. in effort to implement the ideal types into the context of rational choice theory (Koppl and Whitman 2004), in treating free market as an ideal-typical construct (Boettke 1997) or by analyzing the standing of behavioral economics that challenges important assumptions of neoclassical and Austrian approach (Rizzo 2012; Špecián 2012). Here, I will try to reconstruct probably the most important Schutzian-Austrian debate that developed around the problem of coordination and spontaneous order (Boettke 1990; Foss 1996; Knudsen 2004; Nasu et al. 2009; Storr 2010c).

\section{Spontaneous Order and Interpretive Social Science}

Spontaneous order is central already to Hayek's famous lecture Economics and Knowledge (1937). It is an outcome of human agency but not of human design. Although the goals and interests of agents in the social system are not coordinated by any individual mind and cannot be even known to it because of their subjective nature, there is a spontaneous coordination visible throughout the whole socio-economic system. Every individual agent is acquainted only with his or her own "ecological niche", or social context that is relevant with respect to his/her own personal interests. Spontaneous order is remarkable, in the first place, because even when everyone is directed by their own aims (which is not to be mixed up with narrowly defined selfishness) there is no chaos of "atomized" individuals. Big masses of people in the society coordinate their expectations regarding the actions of others and accommodate their own actions to these expectations so as to create a harmony and fluency in interhuman relations most of the times.

Because description of the social world is the goal of Schutzian understanding sociology, it cannot resign on dealing with the problem of spontaneous order (Boettke 1990; 1998). As Foss (1996) shows, mainstream economic theory has hard time explaining where the social coordination originates - the problem of spontaneous 
order is either "assumed away" using an assumption of perfect information (Ricardo, rational expectations) or cancelling social action and creating from individual agents "monads with no windows" using the notion of Walrasian auctioneer. Game theory, the most powerful economic tool to deal with strategic interaction, struggles with problem of multiple equilibria where there is no a priori reason why a rational agent should pick a particular one (Sugden 1989).

The key to existence of spontaneous order are institutions, conventions and norms that cannot be easily reduced to rational maximization and thus ignored by economic analysis. Sugden (1989), fairly within the Hayekian tradition, talks about the evolutionary dimension of the development of rules that allow social coordination. Foss (1996) who carries the analysis further shows, nevertheless, that the analogy of biological evolution is not the only feasible solution ${ }^{4}$ and that the whole problem of coordination can be equally well or even better captured using the Schutzian notions of typification and structures of relevance. An institution is nothing more than a shared course-of-action type (Foss 1996, 81) which is something the agents gain in the process of socialization described by Schutz (1972) as entering the world shared with others that is characteristic with abstract notions of anonymous typified agency (personal ideal types as "bank clerk" or course-of-action types as "exchange/trade"). Institutions are thus seen as Pygmalion's statues - human creations that gained their own sort of independent life. Only assuming the shared typifications and structures of relevance which are based on an invariant structure on the lifeworld or common culture can we make some sense from e.g. Schelling's focal points that allow us to solve coordination games with multiple equilibria.

"... in Schutzian terms, classical game theory wants us to operate with a too anonymous ideal-type of the rational player, one that is only given by his utility function and rationality. But surely, in most interaction we know more about other players than simply the fact that they are persons that rationally pursue certain ends; the typifications we use are in reality much richer." (Foss 1996, 83)

Schutzian method of "telescopic ideal type" (Prendergast 1986) that works with ideal types of different degrees of abstraction seems therefore suitable also for solving questions connected with the spontaneous order. It encompasses everything from the fully abstract economic models that neglect all historical, institutional and biographical circumstances of human action to the ideal types used in microsociological and anthropological studies where the circumstances are of highest relevance and general "model" principles almost completely covered in the garb of incidental facts.

${ }^{4}$ Moreover, the analogy of biological evolution can be misleading because of rather Lamarckian than Darwinist character of social evolution (see Rosenberg 2000). 
But: Isn't such an effort to analyze spontaneous order just an ad hoc application of Schutzian terminology in a realm that actually cannot be reached from phenomenological positions? If the spontaneous order is not designed by any individual mind haw can we capture it on the level of individual consciousness at all? Storr (2010c) addresses and partly also solves this problem: Schutzian methodology does not require an originary experience of the thing itself as a foundation of every typification. Such originary experience would be, of course, impossible with spontaneous order that is defined through not being graspable by any individual mind. What an approach inspired by Schutzian ideal types actually needs is just a continuity between naïve constructs of the first order and scientific second order constructs - the aim is to prevent science from tearing itself completely apart of the lifeworld of the agents it tries to describe and explain. Therefore, all that is needed for a justified application of Schutzian approach is an existence of some naïve typified notion of social order that can be used by science to build upon. This notion does not have to be developed on a basis of consciousness of the order as such (a view from outside) - it can be based on a synthesis of many typical courses of action we encounter in our daily lives or on an experience with anonymous social forces (a view from inside). One way or the other, our everyday experience with social coordination and social forces makes each of us into a theoretician of a spontaneous order, at least to some extent (Storr 2010c).

Naïve theories of the spontaneous order can, of course, be vague and imprecise. They may completely miss the invisible hand principle or fall for the broken window fallacy as research on folk economics (see e.g. Rubin 2003) suggests. That still does not mean that they provide no foundations for the scientific approach that can more or less fluently take up where they have failed - Schutzian methodological claims are therefore not violated.

\section{Conclusion}

Schutzian approach goes, due to its phenomenological roots, much more in a direction of epistemology than Hayek's concept of cultural evolution does. Schutz cannot answer the question of the origin of spontaneous order that has no correlate in individual consciousness (see Pavlík 2004). Nevertheless, we can still use Schutz's understanding sociology and his methodology when solving the problems connected with the reproduction of this order which happens through the means of socialization and gradual constitution of our image of the world including the primitive models of social coordination that can be traced to the individual consciousness. Because the theory of social evolution faces many obstacles mainly due to its vague Lamarckian character, this sociological approach can be quite attractive to many. Further clarification of this question is to be expected from an ongoing research. 


\section{Bibliography}

Boettke, Peter J. 1990. "Interpretive Reasoning and the Study of Social Life." Methodus: Bulletin of the International Network for Economic Method, 2 (2): 35-45.

- - - 1997. "Where Did Economics Go Wrong? Modern Economics as a Flight from Reality." Critical Review, 11 (1): 11-64.

- - - 1998. "Rational Choice and Human Agency in Economics and Sociology: Exploring the Weber-Austrian Connection." In Merits and Limits of Markets, ed. Herbert Giersch. Springer.

Foss, Nicolai Juul. 1996. "Spontaneous Social Order: Economics and Schutzian Sociology." American Journal of Economics and Sociology, 55 (1): 73-86.

Gadamer, Hans-Georg. 2004. Truth and Method. 1st ed. Continuum.

Grathoff, Richard, ed. 1989. Philosophers in Exile. Bloomington: Indiana University Press.

Hayek, F. A. 1937. “Economics and Knowledge.” Economica, 4 (13): 33-54.

Hoppe, Hans-Hermann. 1989. “In Defense of Extreme Rationalism: Thoughts on Donald McCloskey's The Rhetoric of Economics." The Review of Austrian Economics, 3 (1): 179-214.

Klein, Daniel. 1999. What Do Economists Contribute? NYU Press.

- - - 2001. "Plea to Economists Who Favor Liberty: Assist the Everyman." Eastern Economic Journal, 27 (2): 185-202.

Knudsen, Christian. 2004. "Alfred Schutz, Austrian Economists and the Knowledge Problem." Rationality and Society, 16 (1): 45 -89.

Koppl, Roger, and Douglas Glen Whitman. 2004. "Rational-choice Hermeneutics." Journal of Economic Behavior E Organization, 55 (3): 295-317.

Lachmann, Ludwig M. 1976. "From Mises to Shackle: An Essay on Austrian Economics and the Kaleidic Society." Journal of Economic Literature, 14 (1): 54-62.

Lavoie, Don. 1994. “The Interpretive Turn." In The Elgar Companion to Austrian Economics, ed. Peter J. Boettke, 54-62. Edward Elgar Publishing.

- - - 2011. "The Interpretive Dimension of Economics: Science, Hermeneutics, and Praxeology." The Review of Austrian Economics, 24 (2): 91-128. 
Lyotard, Jean Francois. 1992. The Postmodern Condition. Minneapolis: University of Minnesota Press.

McCloskey, Deirdre. 1983. “The Rhetoric of Economics." Journal of Economic Literature, 21 (2): 481-517.

- - - 1996. The Vices of Economists, the Virtues of the Bourgeoisie. Amsterdam: Amsterdam University Press.

Mises, Ludwig von. 2010. Human Action: The Scholar's Edition. Ludwig von Mises Institute.

Nasu, Hisashi, Lester Embree, George Psathas, and Ilja Srubar, ed. 2009. Alfred Schutz and His Intellectual Partners. Konstanz: UVK.

Pavlík, Ján. 1998. "Filosofie, Ekonomie a Konec Postmodernismu." Acta Oeconomica Pragensia, 6 (3): 75-154.

- - - 2004. F. A. Hayek a Teorie spontánního řádu. Praha: Professional Publishing.

Prendergast, Christopher. 1986. "Alfred Schutz and the Austrian School of Economics." American Journal of Sociology, 92 (1): 1-26.

Rizzo, Mario J. 2012. “Austrian Economics Meets Behavioral Economics: The Problem of Rationality." URL: <http://works.bepress.com/mario_rizzo/31>, [cit. 10. 1. 2013].

Rorty, Richard. 2009. Philosophy and the Mirror of Nature: Thirtieth-Anniversary Edition. Princeton University Press.

Rosenberg, Alex. 2000. “Does Evolutionary Theory Give Comfort or Inspiration to Economics?" In Darwinism in Philosophy, Social Science and Policy, 172-94. Cambridge University Press.

Rothbard, Murray N. 1989. "The Hermeneutical Invasion of Philosophy and Economics." The Review of Austrian Economics, 3 (1): 45-59.

- - . 1996. "Intimidation by Rhetoric." The Review of Austrian Economics, 9 (1): 173-78.

- - - 2011. "Praxeology as the Method of the Social Sciences." In Economic Controversies, 29-58. Auburn: Luwig von Mises Inst.

Rubin, Paul H. 2003. "Folk Economics." Southern Economic Journal, 70 (1): 157-71. 
Schutz, Alfred. 1972. The Phenomenology of the Social World. Evanston, Ill.: Northwestern University Press.

Storr, Virgil Henry. 2010a. “On the Hermeneutics Debate: An Introduction to a Symposium on Don Lavoie's 'The Interpretive Dimension of Economics - Science, Hermeneutics, and Praxeology'." The Review of Austrian Economics, 24 (2): 85-89.

- - - 2010b. "Schutz on Meaning and Culture." Review of Austrian Economics, 23 (2): 147-63.

- - . 2010c. "Schutz On Objectivity and Spontaneous Orders." Schutzian Research 2: $163-79$.

Sugden, Robert. 1989. "Spontaneous Order." The Journal of Economic Perspectives, 3 (4): 85-97.

Špecián, Petr. 2011. “Alfred Schütz - Od Husserla k rakouské ekonomii." E-Logos : Electronic Journal for Philosophy, 2011 (9): 1-25.

- - - 2012. “Od Misese k Schutzovi. Otázka apriorismu v ekonomii." Politická ekonomie, 60 (3): 395-410.

Vaněk, Jiří. 2004. "Fenomenologická metodologie společenských věd a možnosti jejího uplatnění v ekonomii." In Filosofické základy metodologie ekonomických věd III,ed. Ján Pavlík. Praha: Oeconomica. 


\section{E-LOGOS}

ELECTRONIC JOURNAL FOR PHILOSOPHY

Ročník/Year: 2013 (vychází průběžně/ published continuously)

Místo vydání/Place of edition: Praha

ISSN 1211-0442

Vydává/Publisher:

Vysoká škola ekonomická v Praze / University of Economics, Prague

nám. W. Churchilla 4

Czech Republic

13067 Praha 3

IČ: 61384399

Web: http://e-logos.vse.cz

Redakce a technické informace/Editorial staff and technical information:

Miroslav Vacura

vacuram@vse.cz

Redakční rada/Board of editors:

Ladislav Benyovszky (FHS UK Praha, Czech Republic)

Ivan Blecha (FF UP Olomouc, Czech Republic)

Martin Hemelík (VŠP Jihlava, Czech Republic)

Angelo Marocco (Pontifical Athenaeum Regina Apostolorum, Rome, Italy)

Jozef Kelemen (FPF SU Opava, Czech Republic)

Daniel Kroupa (ZU Plzeň, Czech Republic)

Vladimír Kvasnička (FIIT STU Bratislava, Slovak Republic)

Jaroslav Novotný (FHS UK Praha, Czech Republic)

Jakub Novotný (VŠP Jihlava, Czech Republic)

Ján Pavlík (editor-in-chief) (VŠE Praha, Czech Republic)

Karel Pstružina (VŠE Praha, Czech Republic)

Miroslav Vacura (executive editor) (VŠE Praha, Czech Republic) 